5 (2021) <DIGITÁLIS BÖLCSÉSZET>

A krakkói Computational Stylistics Group (Különszám)

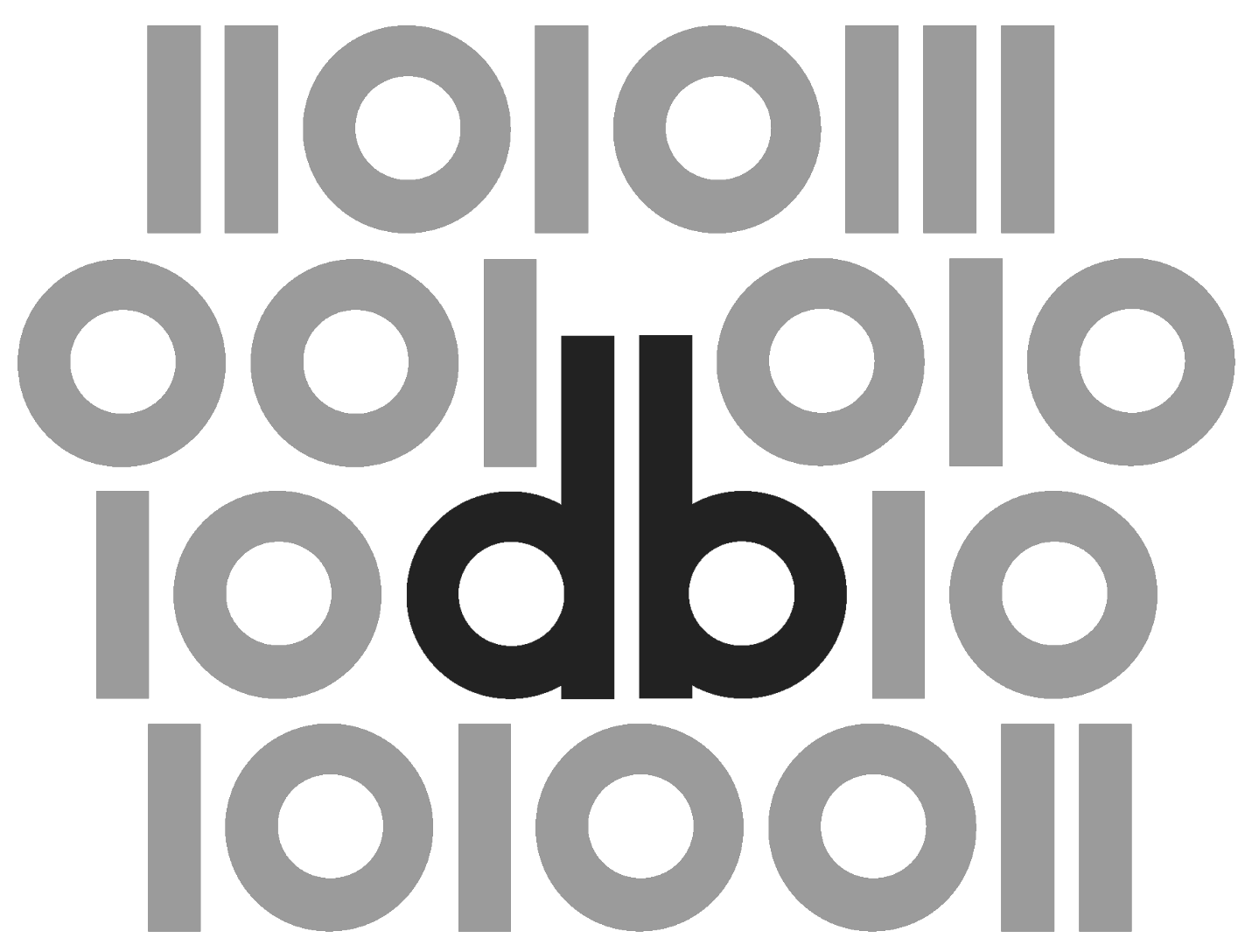

5 (2021) </DIGITÁLIS BÖLCSÉSZET> 
Digitális Bölcsészet 2021., ötödik szám

A krakkói Computational Stylistics Group

(Különszám) 


\title{
〈DIGITÁLIS BÖLCSÉSZET>
}

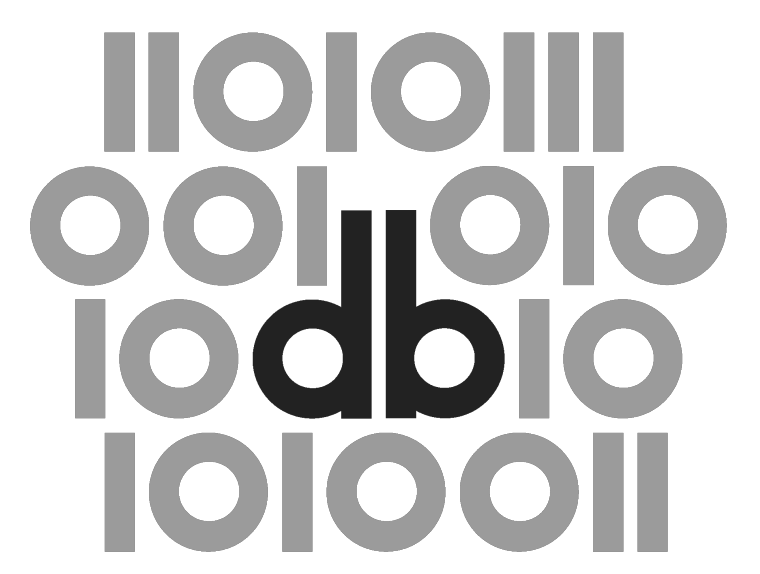

\author{
$5(2021)$ \\ A krakkói \\ Computational Stylistics Group
}

(Különszám) 
A különszámot Szemes Botond szerkesztette.

Felelős szerkesztő :

Maróthy Szilvia

Szerkesztőség:

Kokas Károly, Parádi Andrea

Rovatvezetők :

Tanulmányok: Kiss Margit

Mühely: Péter Róbert

Kritika: Almási Zsolt

Labor: Mártonfi Attila

Tanácsadó testület:

Bartók István, Fazekas István, Golden Dániel, Horváth Iván, Palkó Gábor, Pap Balázs, Sass Bálint, Seláf Levente

Korábbi munkatársaink:

Bartók Zsófia Ágnes (szerkesztő, rovatvezető), Fodor János (szerkesztő),

+Labádi Gergely (szerkesztő, rovatvezető), †Orlovszky Géza (tanácsadó testület)

ISSN 2630-9696

DOI 10.31400/dh-hun.2021.5

Kiadja a Bakonyi Géza Alapítvány és az ELTE BTK Régi Magyar Irodalom Tanszéke (1088 Budapest, Múzeum krt. 4/A).

Felelős kiadó az ELTE BTK Régi Magyar Irodalom Tanszék vezetője.

Megjelenik az Open Journal Systems (OJS) v. 3. platformon, melynek működtetését az ELTE Egyetemi Könyvtár- és Levéltár biztosítja.

A különszám megjelenését a Wacław Felczak Alapítvány támogatta.

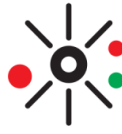

\section{(cc) BY-NC-SA}

Ez a mủ a Creative Commons Nevezd meg! - Ne add el! - Így add tovább! 2.5 Magyarország Licenc (http: //creativecommons . org/licenses/by-nc-sa/2.5/hu/) feltételeinek megfelelően felhasználható.

Honlap: http://ojs.elte.hu/digitalisbolcseszet

Email cím:dbfolyoirat@gmail.com

Olvasószerkesztő: Bucsics Katalin

Tördelés: Hegedüs Béla

Grafika: Hegyi Gábor 


\section{Tartalom}

Joanna Byszuk - Szemes Botond

A krakkói Computational Stylistics Group bemutatkozása Előszó a Digitális Bölcsészet folyóirat tematikus lapszámához . . . . . 3

TANULMÁNYOK

Maciej Eder

Elena Ferrante $:$ Egy „virtuális” szerző . . . . . . . . . . . . . . . 3

Jan Rybicki

Vive la différence!

Írók nemének azonositása többváltozós szógyakorisági elemzések során . 19

Greta Franzini - Mike Kestemont - Gabriela Rotari - Melina Jander -

Jeremi K. Ochab - Emily Franzini - Joanna Byszuk - Jan Rybicki

Szerzőazonositás facob és Wilhelm Grimm zajos, digitalizált

levelezésében . . . . . . . . . . . . . . . . . . . . 39

Artjoms Šel̦a - Boris Orekhov - Roman Leibov

Gyenge müfajok

A költői versmérték és a jelentés közötti kapcsolat modellálása

az orosz költészetben . . . . . . . . . . . . . . . . . . . . . . . . 69

Albert Leśniak- Zbigniew Pasek

Neoprotestáns és katolikus tanúságtételek a korpuszalapú

diskurzuselemzés perspektívájából . . . . . . . . . . . . . . . 91

Helena Grochola-Szczepanek - Ruprecht Von Waldenfels -

Rafał L. Górski - Michał Woźniak

A szepességi lengyel nyelvjárás korpusznyelvészeti elemzése . . . . . . . 113 
Joanna Byszuk (i) 0000-0003-2850-2996

Instytutu fezyka Polskiego PAN

joanna.byszuk@ijp.pan.pl

Szemes Botond (10) 0000-0002-0637-6776

ELTE BTK Irodalomtudományi Doktori Iskola; ELTE BTK Digitális Bölcsészet Tanszék

boboszemes@gmail.com

\section{A krakkói Computational Stylistics Group bemutatkozása}

\section{Előszó a Digitális Bölcsészet folyóirat tematikus lapszámához}

A „stilometria” fogalmát a világhírü lengyel filológus-filozófus-nyelvész, Wincenty Lutosławski alkotta meg a 19-20. század fordulóján, amikor Platón dialógusainak időrendjét a bennük előforduló nyelvi elemek gyakoriságvizsgálatán keresztül kívánta meghatározni. ${ }^{1}$ Módszerének sok követője akadt, ám a valódi előrelépést a számítástechnika elterjedése hozta el a területen: a nyelvi elemek statisztikai vizsgálatát innentől kezdve már nagy korpuszokra kiterjesztve és ellenőrzött módon lehet megvalósítani. A számítógépes stíluskutatás legjelentősebb képviselői közül sokan - Lutosławskihoz hasonlóan - szintén Lengyelországból érkeznek, akik elsősorban a krakkói székhelyű Computational Stylistics Group kutatócsoportjába tömörülnek. ${ }^{2}$ Az alábbi folyóiratszám e kutatócsoport munkájába nyújt bepillantást a tagok által írt tanulmányok fordításain keresztül.

A stilometria - a Magyarországon is nagy hagyományokkal rendelkező kvantitatív stilisztikához hasonlóan - egy meglehetősen egyszerű elképzelésből indul ki: egy szerző, egy mü vagy egy szövegcsoport stílusa meghatározható a rá jellemző vagy nem jellemző összetevői (pl. szavak, nyelvtani szerkezetek) alapján; így, ha ezeket megfelelő módon azonosítani tudjuk, akkor az előfordulásokat összeszámolva a szövegek stílusa kvantifikálható és összehasonlítható lesz, valamint eddig nem reflektált

1 Wincenty Lutołsawski, The Origin and Growth of Plato's Logic: With an Account of Plato's Style and of the Chronology of His Writings (London: Forgotten Books, 2018 [1890]).

2 A kutatócsoport egy intézményközi szervezet, amelynek tagjai leginkább a Lengyel Nyelvtudományi Intézetben (Lengyel Tudományos Akadémia) a Jagelló Egyetemen és az Antwerpeni Egyetemen működnek. A kutatócsoport honlapja, hozzáférés: 2021.12.13, https ://computationalstylist ics.github.io/. 
tulajdonságaik is láthatóvá válhatnak. ${ }^{3}$ Hiszen egy ilyen gyakoriságvizsgálat a nyelvi működés más szintjére vonatkozik, mint az olvasás művelete - térbeli metaforával élve a szövegek „mélystruktúráira” irányul. A stilometriai kutatások eredményei ennek megfelelően a szerzőazonosítás ${ }^{4}$ területén érték el a leginkább szembetűnő sikereket; a számítógépes kapacitást kihasználva ugyanis bizonyíthatóvá vált, hogy minden szerzőre (de akár korszakra, műfajra, vagy más szövegcsoportra) egyénileg jellemző az általa használt szavak eloszlása: azaz a leggyakoribb ${ }^{5}$ szavak előfordulását mérve elkülöníthetők az egyes alkotók szövegei egymástól - aminek segítségével az ismeretlen szerzőségű művek írója is meghatározható lehet. ${ }^{6}$ Ebből is látható, hogy mit jelent a „mélystruktúra” megjelölés, hiszen egy szövegben a leggyakrabban a konkrét jelentést nélkülöző úgynevezett funkciószavak (pl. névelők, kötőszavak) fordulnak elő, így ezek eloszlása nem a művek szemantikai karakteréről értesít bennünket, hanem az adott íróra jellemző nyelvhasználatról, vagyis - újabb beszédes metaforát alkalmazva - a „szerzői ujjlenyomat” jelenlétéről. ${ }^{7}$

Ez az egyszerü elképzelés akkor válik összetetté, ha átültetjük a gyakorlatba, és rákérdezünk arra, hogy milyen nyelvi elemeket, milyen korpuszokon és hogyan érdemes azonosítani, illetve összeszámolni a statisztikai alapú stíluskutatás során. A Computational Stylistics Group munkássága innen nézve válik megkerülhetetlenné, hiszen ennek előterében a módszertani kísérletezés, az optimális működés megtalálása és más kutatók számára erre vonatkozó ajánlások megfogalmazása áll. Ennyiben pedig a digitális bölcsészet alapvetően kísérletező jellegét erősíti meg és teszi látványossá, amely talán a diszciplína egyik legfontosabb sajátosságaként jelölhető meg. ${ }^{8}$ Ennek

3 Ugyan a stilometria a szövegelemzés területén alakult ki, meg kell jegyezni, hogy manapság más médiumok és művészeti ágak (pl. zene, színház, film) esetében is alkalmazzák a fent kifejtett módszert. A lapszám ugyanakkor olyan tanulmányokat közöl, amelyek az irodalom- és nyelvtudomány viszonyában hasznosítják a statisztikai alapú stíluskutatás belátásait.

4 A korábbi magyar nyelvü tanulmányokat követve ezt a kifejezést használjuk a lapszámban. Ez azonban annyiban különbözik a nemzetközi szakirodalomban használatos angol authorship attribution megjelöléstől, hogy annak 'szerzőség hozzárendelés' jelentése magában foglalja, hogy az eredmények nem az 'azonosítás' bizonyosságára, hanem a valószínűségek között mozgó kutatás konstrukcióira vonatkoznak.

5 Általában azért a leggyakoribb szavak vizsgálata kerül az előtérbe, mivel ezek biztosítanak statisztikailag elegendő mennyiségű adatot a következtetések számára.

6 Ennek a módszernek az alapítószövege: John Burrows, „Delta’: A Measure of Stylistic Difference and a Guide to Likely Authorship," Literary and Linguistic Computing 17, 3. sz. (2002): 267-287, https://doi .org/10.1093/11c/17.3.267.

7 Ehhez lásd Maciej Eder, „Style-Markers in Authorship Attribution: A Cross-Language Study of the Authorial Fingerprint,” Studies in Polish Linguistics 6 (2011): 99-114.

8 A digitális bölcsészet ilyen irányú meghatározását lásd Ted Underwood, „A Genealogy of Distant Reading," DHQ 11, 2. sz. (2017), http: //www . digitalhumanities.org/dhq/vol/11/2/000317/ $000317 . h t m l$. 
megfelelően kísérleteket végeztek, hogy milyen, ${ }^{9}$ illetve hány darab ${ }^{10}$ nyelvi elemen keresztül és legkevesebb hány szóból álló szövegeket vizsgálva ${ }^{11}$ érhető el legjobban a szövegek/szerzők megkülönböztető stílusa, milyen metrikák segítségével ragadható meg ez a különbség, ${ }^{12}$ hogyan érdemes a kiinduló tanítókorpuszt létrehozni, ${ }^{13}$ és milyen vizuális megjelenítés tudja a szövegek közötti kapcsolatokról a legtöbb információt láthatóvá tenni. ${ }^{14}$ Ezek a kísérletek két szempontból is alapvető fontosságúak. Egyrészt mivel a kortárs stilometria a digitális bölcsészet részeként nem csupán a kvantitatív stilisztika hagyományához kapcsolódik, hanem erősen támaszkodik az adattudomány és a statisztika eljárásaira is - a hivatkozott tanulmányok pedig megkerülhetetlen szerepet játszanak abban, hogy ezeket az eljárásokat ne pusztán átvegyék a bölcsészeti érdekeltségü projektek, hanem azokat megértve saját céljaikhoz legyenek képesek igazítani. Másrészt az említett vizsgálatokat nemcsak a módszereknek, hanem magának a nyelvi müködésnek a jobb megértése is motiválja, azaz hogy milyen olyan eloszlások, törvényszerüségek, történeti alakulások figyelhetők meg az irodalmi és hétköznapi nyelvhasználatban a kvantitatív megközelítések segítségével, amelyek korábban nem voltak láthatók - és ezek hogyan köthetők a kvalitatív megközelítések eredményeihez.

Fontos megemlíteni, hogy a kutatócsoport nem csupán tanulmányok formájában kommunikálja eredményeit, hanem nagy hangsúlyt fektet eljárásaik és szemléletük tanítására is. Számtalan workshop, nyári egyetem, ${ }^{15}$ blogbejegyzés ${ }^{16}$ és a módszerek elsajátítását segítő anyag kifejlesztése mellett gyakran fogadnak vendégeket szemé-

9 Például Mike Kestemont, „Function Words in Authorship Attribution: From Black Magic to Theory?” in Anna Feldman, Anna Kazantseva and Stan Szpakowicz, eds., Proceedings of the 3rd Workshop on Computational Linguistics for Literature (CLFL), 59-66 (Gothenburg: Association for Computational Linguistics, 2014), http://doi .org/10.3115/v1/W14-0908. Jan Rybicki and Maciej Eder „Deeper Delta Across Genres and Languages: Do We Really Need the Most Frequent Words?” Literary and Linguistic Computing 26, 3. sz. (2011): 315-321, https ://doi .org/10.1093/1lc/fqr031.

10 Jan Rybicki, „Reading Novels with Statistics: What Numbers of Words Tell Us about Authorship, Genre, or Chronology," in John August Dobelman, ed., Models and Reality: Festschrift For James Robert Thompson, 207-224 (Chicago: T\&NO Company, 2017).

11 Maciej Eder, „Does Size Matter? Authorship Attribution, Small Samples, Big Problem,” Digital Scholarship in the Humanities 30, 2. sz. (2015): 167-182, https ://doi.org/10.1093/llc/fqt066. Maciej Eder, „Short Samples in Authorship Attribution: A New Approach,” in Rhian Lewis, Cecily Raynor, Dominic Forest, Michael Sinatra and Stéfan Sinclair, eds., dh2017: Digital Humanities 2017, Conference Abstracts, McGill University \& Université de Montréal, Montréal, Canada, August 8-11, 2017, 223 (Montréal: Alliance of Digital Humanities Organizations [ADHO], 2017).

12 Ennek kapcsán fontos megemlíteni Burrows Deltájának a flektáló nyelvekre kialakított változatát, Eder Deltáját. Ezeknek elemzéséhez lásd Fotis Jannidis et. al., „Improving Burrows’ Delta - An Empirical Evaluation of Text Distance Measures," in Book of Abstracts of the Digital Humanities Conference 2015, ADHO (Sydney, UWS, 2015).

13 Maciej Eder and Jan Rybicki, „Do Birds of a Feather Really Flock Together, Or How to Choose Training Samples for Authorship Attribution," Literary and Linguistic Computing 28, 2. sz. (2012): 229-236, https://doi.org/10.1093/1lc/fqs036.

14 Maciej Eder, „Visualization in Stylometry: Cluster Analysis Using Networks,” Digital Scholarship in the Humanities 32, 1. sz. (2017): 50-64, https ://doi .org/10.1093/llc/fqv061.

15 A legnagyobbakat említve: Digital Humanities Summer Institute (hozzáférés: 2021.12.13, https : // dhsi.org) és European Summer University in Digital Humanities (hozzáférés: 2021.12.13, https: //esu.fdhl.info/).

16 Hozzáférés: 2021.12.13, https://computationalstylistics.github.io/blog/. 
lyesen is, hogy ismereteiket első kézből tudják átadni az érdeklődő kutatók számára. ${ }^{17}$ Ezen kívül a csoport „DH Lunch” címmel saját előadás-sorozatot szervez, amelynek keretében a világ különböző pontjairól érkeznek előadók, hogy a stilometria eszköztárának egyéni felhasználásairól számoljanak be. ${ }^{18}$ Tevékenységeik közül azonban minden bizonnyal az R programozási környezetre kifejlesztett, Stylo programcsomag ${ }^{19}$ gyakorolta a legnagyobb hatást a digitális bölcsészeti közösségre. A csomag magába foglalja a stilometriai kutatás minden lépését a korpuszok előkészítésétől a gyakoriságvizsgálat paramétereinek beállításán és az eredményeken végzett statisztikai eljárásokon át a szövegek hasonlóságának/különbségének kiszámításáig és a viszonyok különféle vizuális megjelenítéséig. Ennek kifejlesztésekor szintén elsősorban a felhasználóbarát, széles körü használat szempontjai érvényesültek, amelynek eredményeképp a Stylo kifejezetten elterjedté vált a szerzőazonosításra és más, szövegek stílusára irányuló digitális bölcsészeti projektekben. ${ }^{20}$ Ezt erősíti tovább az oktatóanyagok fejlesztése és a stilometria területén dolgozó kutatóközösséggel tartott szoros kapcsolat: az említett fórumokon kívül érdemes még megemlíteni a programcsomag működése kapcsán felmerült kérdések számára kialakított felületet, ${ }^{21}$ valamint az új felhasználóknak szóló oktatóvideókat is. ${ }^{22}$

A folyóiratszámban közölt tanulmányok ugyanakkor túlmutatnak az említett alapkutatásokon, amennyiben konkrét - elsősorban irodalom- és nyelvtudományi - kérdések megválaszolását tűzik ki célul. Azonban ezek a kutatások is kísérletként valósulnak meg, hiszen rendszerint különböző módszerek teljesítményét ütköztetik egymással, sőt az eredményeket is inkább mint valószínűségeket prezentálják, jelezve az azokból levonható következtetések határait. Miközben ez a tudatosság természetesen nem gátolja meg a szerzőket abban, hogy óvatos, de alapvető irodalom- és kultúrtörténeti összefüggéseket vázoljanak fel a kísérletek alapján.

Az első három tanulmány szorosan összetartozik és egy külön blokkot alkot a lapszámon belül. Mindegyik szöveg a szerzőazonosítás témaköréhez kapcsolódik, ugyanakkor annál tágabb horizontot fognak át, mivel kérdéseik nem csupán az ismeretlen szerzőségű művek alkotójának azonosítására irányulnak. Maciej Eder tanulmánya az

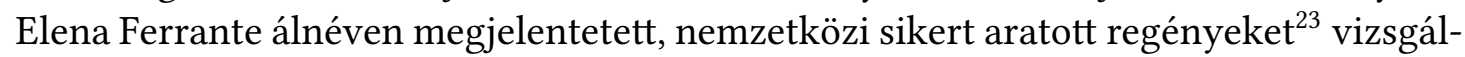

17 Így került a kutatócsoporttal kapcsolatba jelen folyóiratszám vendégszerkesztője és az előszó társszerzője, Szemes Botond is.

18 A rögzített előadások szintén szabadon megtekinthetők, hozzáférés: 2021.12.13, https://www.yo utube.com/channel/UCQfYhxastnHg6jiZU-H3PLA/videos.

19 Maciej Eder, Jan Rybicki and Mike Kestemont, „Stylometry with R: A Package for Computational Text Analysis," R fournal 8, 1. sz. (2016): 107-121, https ://doi .org/10.32614/RJ-2016-007.

20 A csomag hazai fejlesztésű, webes alkalmazása Shtylo néven érhető el: Dobi Jan Sándor, Mészáros Tamás és Kiss Margit, „Shtylo: Stilometriai elemzések webes támogatása, in Vincze Veronika, szerk., XIV. Magyar Számítógépes Nyelvészeti Konferencia, 423-436 (Szeged: Szegedi Tudományegyetem Informatikai Tanszékcsoport, 2018). Ez utóbbi fejlesztést alkalmazta Kiss Margit, a folyóirat szerkesztője is tanulmányában: Kiss Margit, „Stilometriai elemzés lehetőségei magyar történeti szövegkorpuszon," Digitális Bölcsészet 2 (2019): 15-33.

21 Hozzáférés: 2021.12.13, https://groups.google.com/g/computationalstylistics.

22 Hozzáférés : 2021.12.13, https : //www. youtube. com/watch?v=Rv7u4UNZJrA.

23 Amelyek közül már nagy költségvetésű filmadaptáció is készült: éppen idén szeptemberben a Velencei Filmfesztiválon került bemutatásra $A z$ elveszett gyerek története című regényen alapuló játékfilm. 
ja, és habár módszereivel komoly érveket szolgáltat az írói név mögött rejlő valódi szerző kilétére vonatkozóan, a kutatás fókuszában mégsem egyszerűen a szerzőség kérdése áll. Jobban érdekli Edert, hogy miután azonosíthatóvá vált a művek valódi szerzője, észlelhető-e a két néven megjelentetett szövegek között stiláris különbség. A leggyakrabb szavakon alapuló vizsgálatai azt bizonyítják, hogy ugyan az álnéven írt szövegek is tartalmazzák valódi írójuk „ujjlenyomatát”, mégis elkülöníthető egymástól a kétféle írói identitás. Külön kiemelendő a dolgozat módszertani sokszínűsége: míg a szerzőazonosításhoz makroperspektívát érvényesít, és 150 olasz regény hálózatát rajzolja fel, addig az egy személyhez tartozó, de különböző írói identitások vizsgálatakor a szövegek apró részleteit elemzi az úgynevezett Rolling Classify (szintén a Stylo-csomagba implementált) módszerével.

Jan Rybicki tanulmánya ugyanígy a szerzőazonosítás kérdéséből indul ki : 18-19. századi angol írónők korpuszában az ismeretlen szerzőségű szövegek alkotójának meghatározására tesz kísérletet, valamint annak ellenőrzésére, hogy nem „keveredett-e” férfi alkotó az írónők közé. Ez a kérdés vezeti el a „férfi” és a „női” írásmód megkülönböztethetőségének igazán izgalmas és nem kevésbé problematikus kérdéséhez - eredményei alapján úgy tűnik, hogy míg a 18. században kulcsszavaik alapján elkülöníthetők egymástól a férfiak és a nők által írt regények, addig a 19. és 20. században ez a szétválasztás már nem lehetséges. A tanulmány, miközben a társadalmi nem kérdésköréhez járul hozzá kvantitatív szempontokkal, érdekes részleteket közöl az angol irodalomtörténet kapcsán is.

A blokk harmadik szövege egyszerre kapcsolódik a Computational Stylistics Group alapkutatásaihoz és mutat fel önálló eredményeket. Az ebben részletezett, nemzetközi kollaboráció során megvalósult projekt leginkább azt a kérdést teszi fel, hogy mennyiben befolyásolja a szerzőazonosítás eredményeit, ha különböző módon és különböző minőségben digitalizált szövegekből áll az elemezni kívánt korpusz. Ennek kapcsán részletesen bemutatják, hogyan müködik a nyomtatott és a kézzel írt szövegek digitalizálása és a betűkarakterek automatikus felismerése - előbbi az OCR (optikai karakterfelismerés), utóbbi a HTR (kézzel írott szövegfelismerés) technikáján alapul. Mindkét eljárás automatikusan ismeri fel a digitalizált karaktereket (a HTR esetében ehhez először létre kell hozni az adott szerző kézírásának modelljét), ám gyakran sok hibával dolgoznak. A digitális bölcsészet kutatói sokszor kényszerülnek így létrejött, különböző minőségű és forrású, „zajos” szövegekre támaszkodni - a tanulmány arra keresi a választ, hogy ezek mennyiben nehezítik meg a szerzőazonosítás feladatát, azaz mennyire „mosódik el” az egyes szerzők „ujjlenyomata” a digitalizálás folyamatában.

Artjoms Šel̦a, Boris Orekhov és Roman Leibov tanulmánya mind módszertanilag, mind a kutatási kérdést tekintve talán a legambiciózusabb vállalkozás a lapszámban. Az orosz költészet kiterjedt korpuszán vizsgálják, hogy a versek metrikai képlete vajon azok tematikus szerveződését is meghatározza-e. A „témák” kijelölésekor jól érzékelhető a digitális bölcsészet hagyományos stíluskutatástól eltérő logikája: a témamodell (topic modelling) algoritmusa mindössze az egymás kontextusában előforduló szavak csoportjait határozza meg; a szerzők pedig nem értelmezik - sőt a főszövegben nem is idézik - ezeket a csoportokat, csupán az egyes versmértékekre jellemző eloszlásukról adnak számot. (Arról, hogy a módszer jól értelmezhető eredményeket is biztosít, a mellékletben közölt eredmények értesítenek: például az ötös trocheushoz korábban 
rendelt „éjszaka”, „táj”, „halál”, „szerelem”, „út” címkékhez hasonló szócsoportokat azonosít az algoritmus is - többek között „tudni, élni, lenni, meghalni, semmi”; „,kert, zöld, levél, ág, hárs”; „menni, ösvény, út, keresztezni, láb”.) A modellek létrehozásakor roppant körültekintő és invenciózus módon járnak el a szerzők; külön érdemes megemlíteni ötletüket, amely szerint, ha a költemények kevésbé gyakori szavait szóbeágyazási módszerrel (word-embedding) a gyakrabban előforduló szinonimákra cseréljük, még hatékonyabb eredményekre vezethet a témamodellezés folyamata. Tesztjeik kimutatják, hogy erős kapcsolat áll fenn az orosz költészeti hagyományban a versmérték és a tartalom között - azaz már a vers formájából következtetni lehet annak szemantikai karakterére. Mindezt a kulturális evolúció (cultural evolution) fiatal tudományterület kereteiben értelmezik, amely azt a folyamatot vizsgálja, ahogyan a társas tanulás során megszerzett információk változnak, fennmaradnak és differenciálódnak az idő során. A szerzők véleménye szerint az általuk azonosított összefüggések és tendenciák általánosan, nyelvektől és irodalmi hagyományoktól függetlenül igazak lehetnek, ami által a versmérték-jelentés kapcsolatban az irodalmi termelés egy alapvető dinamikáját érthetjük meg.

A lapszám utolsó két írása a nyelvészet területéről közelít a digitális bölcsészet és a stilometria felé. Albert Leśniak és Zbigniew Pasek munkájának kiindulópontja, hogy a korpusznyelvészet tulajdonképpen a foucault-i értelemben vett diskurzuselemzés. Ebből az alapállásból kiindulva vetik össze két vallási közösség, a neoprotestáns és a katolikus hívők tanúságtételeinek szövegeit. Ezeknek kulcsszavait és kulcsszavak kollokációit elemezve alapvető különbségekre tudnak rámutatni az egyes közösségek működésében, leginkább a hívőknek a bűnhöz való viszonyát és a megtérés folyamatának időszerkezetét tekintve. Míg a katolikus tanúságtételek elsősorban a szexualitás témája körül forognak, addig a neoprotestáns változatokban inkább a különböző függőségek (alkohol, drog, cigaretta) kerülnek előtérbe a bűnök felsorolásakor; illetve míg a katolikus közösségben éles váltás figyelhető meg a megtérés előtti és utáni időszak között, addig a neoprotestáns elbeszélések a lassabb átmenet sémáját részesítik előnyben.

Az utolsó tanulmány az eddigiekkel szemben kevésbé a saját kutatási eredmények ismertetésében érdekelt. Egy olyan folyamatról számol be, amely minden esetben az eddig elmondottak feltételeként szolgál: magának az elemezni kívánt digitális korpusznak a létrehozásáról. Mivel ezt a kérdést a dialektológia területén járják körül, a lengyel Szepesség digitális és kereshető adatbázisának megalkotásáról szóló írásuk külön érdekes lehet a nyelvjárások és a szociolektusok kutatói számára.

A krakkói Computational Stylistics Group egy nemzetközileg jelentősen beágyazott mühely. Az említett előadás-sorozatokon és workshopokon túl szoros kapcsolatot ápolnak az Antwerpeni Egyetemmel (amellyel külön projektben vizsgálják a deep learning módszerek stilisztikai hasznosíthatóságát ${ }^{24}$ ), az ELTE BTK Digitális Bölcsészet Tanszékéhez hasonlóan tagjai a „Distant Reading for European Literary History” COST Action programnak ${ }^{25}$ és a „CLS Infra” elnevezésű Horizon 2020 projektnek is. ${ }^{26}$ Jelen lapszámmal reméljük, hogy munkásságuk a magyar digitális bölcsészeti közösséghez is közelebb kerül.

24 Hozzáférés: 2021.12.13, https://computationalstylistics.github.io/projects/deep_le arning/.

25 Hozzáférés: 2021.12.13, https://www. distant-reading.net/.

26 Hozzáférés: 2021.12.13, https://clsinfra.io/. 